\title{
Resident Perceptions of Black Bear Management in South Central Kentucky
}

\author{
Hung-Ling Stella Liư ${ }^{1}$, Michael J. Bradley², I-Chun Nicky $\mathrm{Wu}^{3}$, James N. Maples ${ }^{4}$ \\ ${ }^{1}$ Department of Health and Nutritional Sciences, South Dakota State University, Brookings, SD, USA \\ ${ }^{2}$ Department of Recreation \& Park Administration, Eastern Kentucky University, Richmond, KY, USA \\ ${ }^{3}$ Department of Health and Human Performance, Middle Tennessee State University, Murfreesboro, TN, USA \\ ${ }^{4}$ Department of Sociology, Anthropology, and Social Work, Eastern Kentucky University, Richmond, KY, USA \\ Email: stella.liu@sdstate.edu,michael.bradley@eku.edu,nicky.wu@mtsu.edu,james.maples@eku.edu
}

How to cite this paper: Liu, H.-L.S., Bradley, M.J., Wu, I.-C.N. and Maples, J.N. (2019) Resident Perceptions of Black Bear Management in South Central Kentucky. Natural Resources, 10, 271-283. https://doi.org/10.4236/nr.2019.107017

Received: June 14, 2019

Accepted: July 15, 2019

Published: July 18, 2019

Copyright $\odot 2019$ by author(s) and Scientific Research Publishing Inc. This work is licensed under the Creative Commons Attribution International License (CC BY 4.0).

http://creativecommons.org/licenses/by/4.0/ (c) (i) Open Access

\begin{abstract}
The growth and sprawl of the American black bear (Ursus americanus) population have been observed and monitored in the past two decades, especially in south-central Kentucky. To better manage human-black bear interaction and develop informed policy and best practices, the current study sought to 1) understand south-central Kentucky residents' current knowledge of and previous experience with black bears, 2) investigate residents' attitudes toward black bears and regulated hunting in wildlife management; and 3) identify residents' level of acceptance of various black bear related management actions in south-central Kentucky. From February to April 2017, residents of London and Stearns districts (southeastern regions) of the Daniel Boone National Forest, a black bear habitat, were invited to participate in this study. The results from 139 completed surveys showed that residents lacked sufficient knowledge about black bear populations in the region and received minimal information regarding black bear management efforts. In comparison to education efforts and relocation, regulated black bear hunting could be a cost-effective option to promote responsible use of wildlife resources and black bear population control. This study provided lessons and recommendations for black bear management in south-central Kentucky and may be of utilization for any other wildlife conservation areas.
\end{abstract}

\section{Keywords}

Black Bear (Ursus americanus), Wildlife Management, National Forest, Wildlife Tourism, Interpretation, Environmental Education, Kentucky, Hunting, Wildlife Resources, Natural Resources 


\section{Introduction}

Understanding public opinions, values, and behavior toward wildlife is essential for an effective and successful natural resource management for conserving and protecting wildlife [1]. Wildlife managers and researchers have made efforts to incorporate public input, especially residents and stakeholders, in managing black bear populations. Evidence showed the reduction of human-bear conflict led to increasing support of black bear conservation [2] [3]. This is especially true for popular, yet controversial species, like American black bears (Ursus americanus). As a result, in the last few decades, the primary components of black bear management in North American have been raising public awareness, wildlife education, and reducing human-bear conflicts [4].

Residents' attitudes toward large predators vary depending on species. Generally, North Americans hold a positive attitude toward black bears, as they are often described as highly intelligent and aesthetically appealing [5]. Other studies found evidence of negative perceptions toward black bears when related to property damage and general nuisance behavior [6] [7].

Increased human encroachment of bear habitat through recreation activities and urban development has catalyzed human-bear interactions. Koval and Mertig [8] suggested that socially acceptable management practices must be considered when managing human-bear conflict. Traditional trapping and lethal control can be expensive, time-consuming, and deemed inappropriate among some residents [8]. Other studies considered preventative practices that reduce initial human-bear contacts more socially acceptable and effective [9].

The growth and sprawl of black bear populations in North America have been observed and documented in the last two decades [10] [11] [12]. It is reported that Kentucky has a high number of complaints due to increasing black bear population and human-bear conflicts [4]. In protecting resident and visitor safety in natural areas, the Kentucky Department of Fish and Wildlife recognized the importance of raising awareness about growing bear population and educating proper behaviors during black bear encounters [13]. As black bear encounters become increasingly common in south-central Kentucky, public land and wildlife managers seek to understand how residents react to or interact with black bears, in order to better manage human-black bear interaction and develop informed policy and best practices for living in bear country [14].

Previous research efforts, such as reintroduction of black bears [15] [16], historic perspectives in managing black bears [12], black bear population estimation [17], and presentations to visitors regarding black bear management have provided a foundation to managerial decision-making. While these efforts have much merit, few focused on assessing residents' perceptions and attitudes toward black bear management in Kentucky [3]. Assessment of residents has been recognized as site-specific, lacking application across different geographic locations [8] [18] [19]. Therefore, the purposes of this study were to 1) understand south-central Kentucky residents' current knowledge of and previous experience 
with black bears; 2) investigate residents' attitudes toward black bears and regulated hunting in wildlife management; and 3) identify residents' level of acceptance of various black bear related management actions in south-central Kentucky.

\section{Methods}

\subsection{Study Area}

Within central and eastern Kentucky, where the Appalachian foothills transition to the Appalachian Mountains, several designated natural areas, including state forests, nature preserves, wildlife management areas, and parks attract visitors into bear habitat. The Daniel Boone National Forest (DBNF) is one of the more popular natural areas, famous for steep forested slopes, sandstone cliffs and narrow ravines [20]. The DBNF spreads across 21 counties of southern and eastern Kentucky, more than 708,000 acres of national forest. Due to the large protected area, it provides large tracts of bear habitat [21]. It is also a popular destination for residents and visitors of surrounding communities seeking recreation activities including camping, hiking, fishing and rock climbing. Much of the DBNF is scattered among privately owned residential properties and farmlands. The London and Stearns districts of the DBNF were selected for the study, because the properties having a high probability of interaction with or/and exposure to black bear populations.

\subsection{Data Collection and Analysis}

Surveys were administered throughout the London and Stearns districts (southeastern regions) of the Daniel Boone National Forest to residents living near and/or recreating in popular habitat for bear populations. Data was collected from onsite intercept surveys of residents who visited various boat ramps, marinas, picnic areas and designated primitive camping areas. The first adult (18 or older) from each intercepted group was invited for the survey. Survey stations were established near the entrances of the various locations and interviews were conducted in six-hour increments for a total of ten days: February 10, 12, 16, and 18; March 2, 5, 16, 25, and April 1, 3 of 2017. The positioning of each survey station was chosen due to the approximately to potential research participants without interfering with other activities.

A descriptive analysis was applied to summarize the frequencies and percentages of residents' demographics, experience and knowledge about black bear, attitudes toward black bear hunting, and level of acceptance of black bear management actions. The reliability of sub-scales of attitudes toward black bear, including positive attitudes, negative attitudes, and environment and management agreement, were examined by Cronbach $\alpha$. Statistical Package for the Social Sciences 25 (SPSS) was used to compute these analyses.

\subsection{Research Instrument}

The questionnaire was structured to collect information regarding respon- 
dents' knowledge of and perceptions toward black bear populations, exposure to informational pamphlets/flyers, views and opinions of black bears, current/potential wildlife management practices, regulated hunting of black bears, feelings toward wildlife in general, and personal/demographic information. The researchers applied questions from black bear studies in the region [3] [22] [23]. There are three main components in this questionnaire:

The first section was designed to understand survey participants' knowledge and previous experience with black bear in Kentucky. The questions included frequency, location and numbers of black bears seen in the past 12 months. In order to understand the concern for personal safety associated with black bear activities, survey respondents were asked to report their level of concern due to black bear activities on a 4 -piont Likert scale ( $1=$ not at all concerned to $4=$ very concerned). Three questions were applied to understand the residents' perception of change in black bear populations in the past five years and the best explanation of the population change.

Thirteen black bear related attitude statements were used to investigate research participants' attitudes toward black bears, including three negative statements, six positive statements, and three habitat and management related statements. "It is important for me to know black bears exist, even if I never see one" is an example of positive attitudes toward black bears. Examples of negative attitude toward black bears included "black bears are a nuisance" and "I worry about problems bears might cause to my property". Management focused statements were used to understand the public perspectives of black bear management from overall agreement to property specific issues. These statements were derived from other black bear related studies with minor modification to fit the need of this study [2] [3] [24]. Respondents rated their agreement from $1=$ strongly disagree to $7=$ strongly agree.

Research participants were also asked to rate their acceptance of various management actions on a 5-point scale, from $1=$ unacceptable in all cases to $5=$ acceptable in all cases. Also, research participants were asked to report their attitude toward regulated hunting (both general and black bear specific) with support, oppose, and neuter as options. Also, a list of black bear management actions was utilized to assess the publics' perspectives in black bear management strategies including both lethal and non-lethal actions, such as education about human-bear conflicts, situational relocation, regulated bear hunting, and euthanize problem bears [23].

Demographic information collected identified residency, years of residency, pet ownership, age, gender, and types of recreation activities respondents had participated in during the previous twelve months.

\section{Results}

A total of 231 individuals were invited to respond to the surveys, whereas only 182 were willing to participate, resulting in a $60.7 \%$ response rate. Due to miss- 
ing information, 43 cases were removed, and 139 were analyzed. All survey participants self-identified as Kentucky residents residing in Jackson, Laurel, Knox, Whitley and Pulaski Counties in south-central Kentucky (Table 1). Their average length of residency was 31 years. The majority (89\%) of survey participants reported living in unincorporated areas or towns of less than 10,000 residents. Participants consisted of $58 \%$ female and $42 \%$ male residents. The age range of survey participants was 18 to 83 , with a mean of 41 years $(41 \pm 13)$.

\subsection{Residents' Experience and Knowledge about Black Bear}

The results indicated that the majority of respondents, 94\%, were aware that black bears live in Kentucky. Participants reported limited interaction, with only $17 \%$ having seen a black bear within the past 12 months. Of the $16 \%$ that had seen a black bear, only $38 \%$ had seen a black bear more than once in the previous 12 months. The majority (57\%) of bear sightings were along roadways or crossing property owned by the participants (43.2\%). As for participants' concern for personal safety and property because of black bear (Table 2), the results showed that the mean score of concerns ranged from 1.44 to 1.91 on a 4-point

Table 1. South-central Kentucky research participants' demographics.

\begin{tabular}{|c|c|c|}
\hline Demographics & Frequency & $\%$ \\
\hline \multicolumn{3}{|l|}{ Gender } \\
\hline Male & 58 & 41.7 \\
\hline Female & 81 & 58.3 \\
\hline \multicolumn{3}{|l|}{ Age } \\
\hline Range & $18-83$ & \\
\hline Mean & 41.23 & \\
\hline Standard Deviation (SD) & 13.43 & \\
\hline \multicolumn{3}{|l|}{ County of residence } \\
\hline Jackson County & 5 & 3.6 \\
\hline Laurel County & 122 & 87.8 \\
\hline Knox County & 6 & 4.3 \\
\hline Whitley County & 4 & 2.9 \\
\hline Pulaski County & 2 & 1.4 \\
\hline \multicolumn{3}{|l|}{ Population of residential area } \\
\hline City with more than 50,000 residents & 6 & 4.3 \\
\hline City with less than 50,000 residents & 5 & 3.6 \\
\hline Town of less than 20,000 residents & 11 & 7.9 \\
\hline Town of less than 10,000 residents & 42 & 30.2 \\
\hline Unincorporated area (rural) & 75 & 54.0 \\
\hline \multicolumn{3}{|l|}{ Outdoor recreation activities ${ }^{*}$} \\
\hline Camping & 75 & 54.0 \\
\hline Wildlife viewing & 60 & 43.2 \\
\hline Freshwater fishing & 74 & 53.2 \\
\hline Hiking & 73 & 52.5 \\
\hline Hunting & 51 & 36.7 \\
\hline Feeding wildlife & 53 & 38.1 \\
\hline
\end{tabular}

${ }^{\star}$ Check all that apply question. 
Table 2. Concerns of black bear for personal safety/property.

\begin{tabular}{ccc}
\hline Concern $^{*}$ & Mean & S.D. \\
\hline You or a family member being injured by a bear & 1.57 & 0.80 \\
Cost of property damage caused by bears & 1.51 & 0.73 \\
Driving your car in areas where you may hit a bear & 1.64 & 0.83 \\
Safety of your pets that may encounter a bear & 1.91 & 0.96 \\
Stress associated with keeping bears out of trash cans & 1.44 & 0.73 \\
Conflicts with neighbors who feed bears & 1.61 & 0.95 \\
\hline
\end{tabular}

${ }^{\star} 4$-piont Likert scale $(1=$ not at all concerned to $4=$ very concerned $)$. S.D. $=$ Standard Deviation.

Likert scale. Among the concerns related to black bears, "safety of your pet that may encounter a bear" $(M=1.91, S D=0.96)$ and "driving your car in areas where you may hit a bear" $(M=1.64, S D=0.83)$ were two highest concerns ranked by residents. Moreover, as related to black bear information at the study area, over $88 \%$ participants reported they had not received any informational pamphlets or flyers regarding black bears in the area, while only $14 \%$ reported having seen or received any information from state or federal agencies while visiting national forest areas.

The results showed that approximately $45 \%$ of research participants were unsure about the black bear population change over the past 5 years in the region, while $38 \%$ perceived an increasing bear population in the region (Table 3). A smaller portion of participants perceived black bear population change as decreasing (15\%) or remaining the same (3\%). Among those who perceived black bear population as decreasing or remaining the same, "cleaning forest land" and "urban development" were the top two reasons given for no population increase. "Lack of black bear hunting opportunity" and "habitat management" were the top two reasons identified to explain the black bear population change.

\subsection{Attitudes toward Black Bears and Hunting}

Among attitudes toward black bears and hunting, positive attitudinal statements were generally rated higher than negative attitudinal statements and environment and management related statements (Table 4). The statement "It is important for me to know black bears exist, even if I never see one" received the highest score $(\bar{x}=6.29, S D=0.98)$ among all the attitudes statements. This is followed by "bears are an important part of our ecosystem" ( $\bar{x}=6.22, S D=$ $1.11)$ and "black bears should be conserved for future generations" ( $\bar{x}=6.12$, $S D=0.95)$. On the other hand, "black bears are a nuisance" was rated with the lowest score $(\bar{x}=2.55, S D=1.26)$. The mean scores for environment and management statements ranged from 4.52 to 4.91 , out of 7-point scale.

Most participants supported regulated hunting in general $(\mathrm{n}=110,79 \%)$ but were slightly less supportive of hunting black bears $(\mathrm{n}=89,64 \%)$. Only $2 \%(\mathrm{n}=$ 3) opposed general regulated hunting, while $6.5 \%(\mathrm{n}=9)$ opposed regulated black bear hunting. Reasons for the opposition of regulated black bear hunting 
Table 3. Residents' knowledge about black bear population.

\begin{tabular}{lcc}
\multicolumn{1}{c}{ Current Knowledge } & Frequency & Percentage \\
\hline Perceived change population in past 5 years & & \\
Decreased & 21 & 15.1 \\
Remained the same & 4 & 2.9 \\
Increased & 52 & 37.4 \\
Unsure & 62 & 44.6 \\
& & \\
Best explain of decline* & & \\
Urban development & 11 & 44.0 \\
Clearing forest land & 13 & 52.0 \\
Decrease in agriculture & 1 & 4.0 \\
& & \\
Best explain of increase* & & \\
Purchasing of land (conservation) & 4 & 7.4 \\
Lack of black bear hunting opportunity & 21 & 31.5 \\
Habitat management & 23 & 38.9 \\
Increase in food availability & 5 & 9.3 \\
Other & 7 & 13.0 \\
\hline
\end{tabular}

${ }^{*}$ Check all that apply question.

Table 4. Residents attitudes toward black bears in south-central Kentucky.

\begin{tabular}{lcc}
\hline \multicolumn{1}{c}{ Attitudes toward Black Bear* } & Mean & S.D. \\
\hline Positive attitude $(\alpha=0.77)$ & 5.58 & 1.27 \\
I enjoy seeing black bears in natural areas & 5.14 & 1.55 \\
Bears are an important part of our ecosystem & 6.12 & .95 \\
Black bears should be conserved for future generations & 6.22 & 1.11 \\
Bears are not a threat to people & 4.18 & 1.58 \\
Seeing a black bear increases my appreciation of nature & 5.53 & 1.47 \\
It is important for me to know black bears exist, even if I never see one & 6.29 & .98 \\
Negative attitude ( $\alpha=0.63)$ & 2.99 & 1.54 \\
I worry about problems bears might cause to my property & 3.29 & 1.81 \\
Risk of being injured by a bear in a natural area is high & 3.12 & 1.55 \\
Black bears are a nuisance & 2.55 & 1.26 \\
& & \\
Environment and management statement ( $\alpha=0.61)$ & 4.75 & 1.48 \\
People should learn to live with black bears near their homes & 4.86 & 1.60 \\
Black bears are being properly managed in this area & 4.52 & 1.04 \\
State governments should buy land for bear conservation & 4.91 & 1.79
\end{tabular}

were primarily due to that residents believed black bear populations were too low or felt that hunting black bear was cruel and inhumane. Furthermore, approximately $30 \%$ of participants expressed their uncertainty about regulated black bear hunting, whereas only $18 \%$ expressed their uncertainty about general regulated hunting activities. Only one participant had participated in hunting black bears in the past, while over $65 \%$ of respondents stated they would not participate in regulated hunting of black bears.

\subsection{Acceptance of Black Bear Management Actions}

Among the potential black bear management actions (Table 5), "educate the 
Table 5. Residents' acceptance level of various black bear management actions.

\begin{tabular}{ccc}
\hline Management Statement & Mean & $S D$ \\
\hline Educate the public about human-bear conflicts & 4.80 & 0.48 \\
Encourage people to relocate or remove bear attractants & 4.28 & 1.08 \\
Condition bears to stay away from urban areas & 4.20 & 0.89 \\
Capture and relocate urban bears & 4.14 & 0.79 \\
Use regulated hunting to manage bear numbers & 3.86 & 1.06 \\
Leave bears alone & 3.60 & 1.05 \\
Euthanize bears that repeatedly cause problems for people & 3.24 & 1.21 \\
Euthanize black bears captured in urban areas & 2.25 & 1.18 \\
\hline
\end{tabular}

*Measured by 5-point Likert scale ranged from 1 "unacceptable in all case" to 5 "acceptable in all case." $S D=$ Standard Deviation.

public about human-bear conflicts" received the greatest level of acceptance $(\bar{x}=$ $4.80, S D=0.48$ ), followed by "encourage people to relocate or remove bear attractants" ( $\bar{x}=4.28, S D=1.08)$ and "condition bears to stay away from urban areas" ( $\bar{x}=4.20, S D=0.89)$, all of which are non-lethal management actions. Among lethal management actions, "use regulated hunting to manage bear numbers" ( $\bar{x}=3.86, S D=1.06)$ received the higher level of acceptance comparing to "euthanize bears that repeatedly cause problems for people" $(\bar{x}=$ $3.24, S D=1.21)$ and "euthanize black bears captured in urban areas" $(\bar{x}=2.25$, $S D=1.18)$.

\section{Discussion}

Kentucky, especially south-central Kentucky near Appalachia, shows a considerable black bear population increase [14]. It is important for management agencies to address the potential conflicts between residents and black bears and to seek possible management actions in preventing future issues [11] [25]. Understanding social factors, such as individuals' attitudes and values about black bears, an acceptable level of conflicts, and management preference could be essential to formulate socially validated managerial strategies [24] [25]. With the black bear population growth in south-central Kentucky, the research findings served as the basis for future outreach and collaboration efforts, such as stakeholder identification, agreement initiation, and public-private partnerships development.

\subsection{Limited Knowledge and Concerns about Black Bear}

The majority of the south-central Kentucky residents in the study were generally aware black bears live in Kentucky; however, they had limited encounter with black bear populations in the region. These residents did not report a considerable concern with their personal and property safety, while they are aware of the potential damages from black bear activities in south-central Kentucky. Although residents feel that black bears are properly managed, resident percep- 
tions may become less favorable if bear populations continue to rise and human-bear interactions increase [26]. Positive personal experience with black bears in one's local area might reduce risk perception when in a recreational setting [11]. Increasing public awareness of black bear behaviors in their area will better prepare residents in the event they encounter a black bear.

The findings also showed that residents expressed their uncertainty about black bear populations change in south-central Kentucky and received minimal information about black bear management efforts. For example, only a small portion of research participants (14\%) had received any informational pamphlets or flyers about black bears in the study area. Approximately $45 \%$ of residents expressed their uncertainty of black bear population growth or decline within the past 5 years. Although most residents expressed their agreement toward black bear management and the responsibilities of DBNF, the level of agreement was approximately 4.8 out of 7-point scale leaning toward "somewhat agree". The result might reveal some level of uncertainty of the current black bear management plan. These results might be indicators that having a sufficient public education about black bear awareness and population change is essential in south-central Kentucky. Lack of personal knowledge about black bears was identified as the most frequent factor resulting in uncertainty of preferred management actions or strategies [6]. Therefore, the DBNF and other managerial agencies could use programs to aid residents in recognizing bears or bear signs in surrounding residential areas and within the forest boundary. For example, social media, signage, or outreach could be applied to increase familiarity with and accurate perceptions of the threats bears do or do not pose to humans [27]. Traditional media exposure of wildlife management is through press releases and printed materials, whereas more media relations programs (e.g. television, social media, etc.) might be better opportunities to craft accurate and useful risk communication [28].

Hosting public forums, additional placement of educational signage, and increased informational pamphlet/flyer distribution should be the focus of wildlife agencies. By increasing knowledge of management practices, agencies can ensure residents have opportunities to become aware of black bear activity/behavior and provide a better public understanding of management practices. While having effective educational programs, land management agencies might need to target specific segments of society by assessing and addressing their values and having education initiatives suited for them. It is also important to assess progress and evaluate outcomes through a comprehensive program evaluation for making needed changes based on both successes and failures of delivery to thrive for a more dynamic and interactive process [4] [29].

\subsection{Support Hunting and Black Bear Management}

Another finding in the study was that south-central Kentucky residents showed strong support for regulated wildlife hunting (79\%) with slightly lesser support for regulated black bear hunting (63\%). It is possible that black bear hunting 
opportunities could be an option for black bear population management in the area. Under certain circumstances, regulated black bear hunting might be considered as an effective and socially acceptable management action and solution to prevent human-bear conflict [32]. Residents were more likely to accept more aggressive management actions (e.g. hunting, trapping, etc.) for conservation and safety purposes rather than recreational purposes or financial gain [31] [32] [33].

Although regulated black bear hunting might not be the most favorable management strategy by all stakeholders, it could be considered as an option to promote a legal and responsible use of wildlife resources and a legitimate and reasonable practice for population control in a cost-effective manner [27]. A well-developed and managed hunting regulation will be able to sustain the ecosystem for black bear and maximize positive values on black bear hunting regarding the economic, social and environmental benefits in the area [30] [34]. Moreover, as for acceptance of black bear management actions, based on the mean score of seven management actions, "use regulated hunting to manage bear numbers" was on the fifth position as residents' acceptance level $(\bar{x}=3.86$, $\mathrm{SD}=1.06$ ). This was after four un-lethal management actions (ex: education efforts, removal of bear attractions, etc.). "Euthanize bears that repeatedly cause problems for people" and "euthanize black bears captured in urban areas" were the two least favorable black bear management actions in the study.

\subsection{Limitations and Future Suggestions}

Some inferential limitations may influence the results of this study. Although interpretation and generalization of the data might be acceptable to some extent, it should be done with caution. While targeting south-central Kentucky residents in the study, the research team collected data at the forest area which tended to gather residents' perspectives from those who might have higher chances for interaction with black bears and/or pay attention to black bear management in the area due to their usage and visits to the forest. The limitation is that research participants were only solicited at common recreation sites within the DBNF. This methodology excludes residents that did not visit these common recreation sites and therefore, results are reflective of resident visitors to the DBNF only. Therefore, future studies could be conducted by using focus groups or mail surveys to select households for further understanding of interaction with black bears and perceptions of black bear management. The management agency should continue to study public attitudes toward black bear management strategies especially for implementing lethal management approaches (e.g. hunting, euthanizing black bears) due to case-specific nature in wildlife management [8] [18]. The second limitation of this study is the results come from a single survey project. A longitudinal research effort should be considered to fully understand the ongoing perceptions of residents as black bear population increasing. The third limitation is the results may be interpreted in a different way by various land and/or wildlife agencies in and around the general area. Depending on the charge of the agency, the results 
could direct management in certain directions to better serve the needs of the agency and those the agency serves.

\subsection{Management Implications}

Managing agencies have determined it is necessary for residents to learn to live in areas of natural bear habitat, even with a majority of participants reporting little to no concern for personal injury or damage to their property from black bears. Increasing public awareness of black bear behaviors in their area will better prepare residents in the event they encounter a black bear. This may assist agencies in efforts to influence resident perceptions regarding the need for relocation of bears near residential property. It might be helpful to have an integrated management regime combining various management strategies: 1) using regulated hunting based on the density and distribution black bear and remove individual nuisance bears; 2) applying aggressive education programs to inform the public about what can be done to avoid human-bear conflicts [23] [34]. By implementing a regulated bear hunting season, agencies could improve public awareness regarding bear populations and improve perceptions of management efforts. It is also worthy to note that some residents might never support certain management actions (e.g. hunting, euthanizing black bears), but learning more about the conditions and rationale for such actions might increase residents' acceptance of these more drastic measures [6].

It is important for agencies to begin taking more proactive measures regarding public awareness of black bear population management. Increased public forums, informational signage, and educational classes that teach residents how to condition their family and property for potential bear interaction will help ensure that the public is properly prepared to live in bear country. Furthermore, managing agencies should increase public awareness of black bear populations while administering socially acceptable management practices. Both increased education and the establishment of hunting seasons will assist agencies to maintain positive resident perceptions of management policy, while conditioning residents to understand the importance of adapting to increasing bear populations.

\section{Conflicts of Interest}

The authors declare no conflicts of interest regarding the publication of this paper.

\section{References}

[1] Kellert, S.R., Black, M., Rush, C.R. and Bath, A.J. (1996) Human Culture and Large Carnivore Conservation in North America. Conservation Biology, 10, 977-990. https://doi.org/10.1046/j.1523-1739.1996.10040977.x

[2] Agee, J.D. and Miller, C.A. (2009) Factors Contributing toward Acceptance of Lethal Control of Black Bears in Central Georgia, USA. Human Dimensions of Wildlife, 14, 198-205. https://doi.org/10.1080/10871200902877829 
[3] Lakes, R.M. and Sharp, R.L. (2015) Visitor Perceptions of Black Bear Management Options in Big South Fork National River and Recreation Area, U.S.A. Human Dimensions of Wildlife, 20, 185-187. https://doi.org/10.1080/10871209.2015.1004765

[4] Spencer, R.D., Beausoleil, R.A. and Martorello, D.A. (2007) How Agencies Respond to Human-Black Bear Conflicts: A Survey of Wildlife Agencies in North America. Ursus, 18, 217-229. https://doi.org/10.2192/1537-6176(2007)18[217:HARTHB]2.0.CO;2

[5] Kellert, S.R. (1994) Public Attitudes toward Bears and Their Conservation. Bears. Their Biology and Management, 9, 43-50. https://doi.org/10.2307/3872683

[6] Morzillo, A.T., Mertig, A.G., Hollister, J.W., Garner N. and Liu, J. (2010) Socioeconomic Factors Affecting Local Support for Black Bear Recovery Strategies. Environmental Management, 45, 1299-1311. https://doi.org/10.1007/s00267-010-9485-3

[7] Decker, D.J., and Purdy, K.G. (1988) Toward a Concept of Wildlife Acceptance Capacity in Wildlife Management. Wildlife Society Bulletin, 16, 53-57.

[8] Koval, M.H., and Mertig, A.G. (2004) Attitudes of the Michigan Public and Wildlife Agency Personnel toward Lethal Wildlife Management. Wildlife Society Bulletin, 32, 232-243. https://doi.org/10.2193/0091-7648(2004)32[232:AOTMPA]2.0.CO;2

[9] Breck, S.W., Lance, N. and Callahan, P. (2006) A Shocking Device for Protection of Concentrated Food Sources from Black Bears. Wildlife Society Bulletin, 34, 23-26. https://doi.org/10.2193/0091-7648(2006)34[23:ASDFPO]2.0.CO;2

[10] Gore, M.L., Knuth, B.A., Curtis, P.D. and Shanahan, J.E. (2007) Campground Manager and User Perceptions of Risk Associated with Negative Human-Black Bear Interactions. Human Dimensions of Wildlife, 12, 31-43. https://doi.org/10.1080/10871200601107882

[11] Siemer, W.F., and Decker, D.J. (2003) 2002 New York State Black Bear Management Survey: Study Overview and Findings Highlights. Cornell University, Ithaca, New York.

[12] Unger, D.E., Cox, J.J., Harris, H.B., Larkin, J.L., Augustine, B., Dobey, S., Guthrie, J.M., Hast, J.T., Jensen, R., Murphy, S. and Plaxico, J. (2013) History and Current Status of the Black Bear in Kentucky. Northeastern Naturalist, 20, 289-308. https://doi.org/10.1656/045.020.0206

[13] Kentucky Department of Fish \& Wildlife (2019) History of Black Bears in Kentucky, Frankfort, KY, USA. https://fw.ky.gov/Wildlife/Pages/Black-Bears.aspx

[14] Gore, M.L., Knuth, B.A., Curtis, P.D. and Shanahan, J.E. (2006) Education Programs for Reducing American Black Bear-Human Conflict: Indicators of Success? Ursus, 17, 75-80. https://doi.org/10.2192/1537-6176(2006)17[75:EPFRAB]2.0.CO;2

[15] Murphy, S.M. (2011) Status of a Reintroduced Black Bear Population in the Big South Fork Area of Kentucky. Master Thesis, University of Kentucky, Lexington, $\mathrm{KY}$.

[16] Murphy, S.M., Cox, J.J., Clark, J.D., Augustine, B.C., Hast, J.T., Gibbs, D., Strunk, M. and Dobey, S. (2015) Rapid Growth and Genetic Diversity Retention in an Isolated Reintroduced Black Bear Population in the Central Appalachians. The Journal of Wildlife Management, 79, 807-818. https://doi.org/10.1002/jwmg.886

[17] Garshelis, D.L. and Hristienko. H. (2006) State and Provincial Estimates of American Black Bear Numbers versus Assessments of Population Trend. Ursus, 17, 1-7. https://doi.org/10.2192/1537-6176(2006)17[1:SAPEOA]2.0.CO;2

[18] Lafon, N.W., McMullin, S.L. and Steffen, D.E. (2003) Knowledge and Opinions of Stakeholders of Black Bear Management in Virginia. Ursus, 14, 55-64. 
[19] Bowman, J.L., Leopold, B.D., Vilella, F.J. and Gill, D.A. (2004) A Spatially Explicit Model, Derived from Demographic Variables, to Predict Attitudes toward Black Bear Restoration. Journal of Wildlife Management, 68, 223-232. https://doi.org/10.2193/0022-541X(2004)068[0223:ASEMDF]2.0.CO;2

[20] USFS (2017) Daniel Boone National Forest Recreation Guide. Washington DC. https://www.fs.usda.gov/Internet/FSE_DOCUMENTS/fseprd559262.pdf

[21] Estep, B. (2012) Daniel Boone National Forest Logging Proposal Withdrawn. Lexington Herald Leader, Lexington, KY. https://www.kentucky.com/news/local/article44377302.html

[22] Bradley, M.J., Sharp, R.L. and Maples, J.N. (2016) Black Bear Populations in the Ouachita Mountains Region of Oklahoma: A Case Study of Management Perceptions and Preferences of Visitors to the 2015 Beavers Bend State Park Folk Festival. Oklahoma Department of Wildlife Conservation.

[23] Liu, H.-L. and Sharp, R.L. (2018) Influence of Attitudes toward Wildlife on Preferences for Management of American Black Bears. Ursus, 29, 32-42. https://doi.org/10.2192/URSU-D-17-00016.2

[24] Don Carlos, A.W., Bright, A.D., Teel, T.L. and Vaske, J.J. (2009) Human-Black Bear Conflict in Urban Areas: An Integrated Approach to Management Response. $\mathrm{Hu}$ man Dimensions of Wildlife, 14, 174-184. https://doi.org/10.1080/10871200902839316

[25] Lowery, D.R., Morse, W.C. and Steury, T.D. (2012) Biological and Social Investigation of Human-Black Bear Conflicts in the Panhandle of Florida. Human Dimensions of Wildlife, 17, 193-206. https://doi.org/10.1080/10871209.2012.660674

[26] Eriksson, M., Sandström, C. and Ericsson, G. (2015) Direct Experience and Attitude Change Towards Bears and Wolves. Wildlife Biology, 21, 131-137. https://doi.org/10.2981/wlb.00062

[27] Wolgast, L.J., Ellis, W.S. and Vreeland, J. (2005) Comprehensive Black Bear (Ursus americanus) Management Policy. New Jersey Fish and Game Council, Black Bear Policy Committee, Trenton, NJ.

[28] Gore, M.L., Siemer, W.F., Shanahan, J.E., Schuefele, D. and Decker, D.J. (2005) Effects on Risk Perception of Media Coverage of a Black Bear-Related Human Fatality. Wildlife Society Bulletin, 33, 507-516. https://doi.org/10.2193/0091-7648(2005)33[507:EORPOM]2.0.CO;2

[29] Can, Ö.E., D’Cruze, N., Garshelis, D.L., Beecham, J. and Macdonald, D.W. (2014) Resolving Human-Bear Conflict: A Global Survey of Countries, Experts, and Key Factors. Conservation Letters, 7, 501-513. https://doi.org/10.1111/conl.12117

[30] Treves, A., Kapp, K.J. and MacFarland, D.M. (2010) American Black Bear Nuisance Complaints and Hunter Take. Ursus, 21, 30-42. https://doi.org/10.2192/09GR012.1

[31] Manfredo, M.J., Pierce, C.L., Fulton, D., Pate, J. and Gill, B.R. (1999) Public Acceptance of Wildlife Trapping in Colorado. Wildlife Society Bulletin, 27, 499-508.

[32] Reiter, D.K., Brunson, M.W. and Schmidt, R.H. (1999) Public Attitudes toward Wildlife Damage Management and Policy. Wildlife Society Bulletin, 27, 746-758.

[33] Ambarli, H. and Bilgin, C.C. (2008) Human-Brown Bear Conflicts in Artvin, Northeastern Turkey: Encounters, Damage, and Attitudes. Ursus, 19, 146-153. https://doi.org/10.2192/1537-6176-19.2.146

[34] Hristienko, H. and McDonald, J.E. (2007) Going into the 21st Century: A Perspective on Trends and Controversies in the Management of the American Black Bear. Ursus, 18, 72-88. https://doi.org/10.2192/1537-6176(2007)18[72:GITSCA]2.0.CO;2 